\title{
Different Modes of Transmissibility and Virus-Vector Relationship in the Occurrence of Leaf Curl Disease of Mesta (Hibiscus subdariffa L.)
}

\author{
Humma Ambuja ${ }^{*}$, D.S. Aswathanarayana ${ }^{1}$, M.R. Govindappa ${ }^{2}$, \\ M.K. Naik ${ }^{3}$ and M.G. Patil ${ }^{4}$ \\ ${ }^{I}$ Department of Plant Pathology, College of Agriculture, UAS, Raichur, India \\ ${ }^{2}$ KVK, Hagari, UAS, Raichur, India \\ ${ }^{3}$ Department of Plant Pathology, University of Agricultural and Horticultural Sciences \\ Shivmogga, India \\ ${ }^{4}$ Department of Horticulture, UAS, Raichur, India \\ *Corresponding author
}

\begin{abstract}
A B S T R A C T
Keywords

Leaf curl virus, Mesta plant, Whitefly ( $B$. tabaci), Dodder,

Potassium phosphate buffer

Article Info

Accepted:

06 December 2017

Available Online:

10 January 2018

Mesta (Hibiscus sabdariffa) is an important commercial fibre crop after cotton and jute, which belong to the family Malvaceae. The crop is mainly grown for a green leafy vegetable purpose in North Karnataka, India. Mesta crop is being affected by many diseases of which leaf curl disease caused by Begomovirus is a main constraint in its production. The disease is observed to be transmitted by different means mainly by whitefly (B. tabaci), dodder (Cuscuta sp.), grafting and sap. Similarly minimum $10 \mathrm{~min}$ of Acquisition Access Period (AAP) and Inoculation Access Period (IAP) is required for the disease transmission and exhibits the disease symptoms. Infected plants exhibited the characteristic symptoms of leaf curl disease as exhibits under natural conditions.
\end{abstract}

\section{Introduction}

Mesta is one of the most important commercial fibre crops after cotton and jute, which belong to the family Malvaceae with chromosome number $2 \mathrm{n}=72$. It is an herbaceous annual crop believed to be originated from Afro- Asian countries. It is more adaptive and drought tolerant than jute under diverse conditions of climate and soil. In Karnataka, the area under mesta cultivation is very less. However, in North Karnataka apart from fiber purpose it can be grown for leafy vegetable as mixed or inter crop in cotton, sugarcane, pigeon pea and vegetable crops. With the irrigation facility the crop can be grown throughout the year as pure crop for leafy vegetable purpose.

The crop is being affected by various diseases such as powdery mildew, leaf spot, root rot, yellow vein mosaic and leaf curl disease (Paul 
et al., 2006). Among the different diseases, leaf curl disease caused by begomovirus is one of the important bottle neck for production and cultivation of mesta in Karnataka. The emergence of the Bemisia tabacibegomovirus complex around the world depends on various factors, such as evolution of variants of the viruses, changes in the biology of vectors, movement of infected planting materials, introduction of new crops and host susceptibility genes through the exchange of germplasm, changes in cropping systems and climatic factors (Varma and Malathi, 2003).

Geminiviruses are classified into seven genera: Mastrevirus, Curtovirus, Topacuvirus, Begomovirus, Becurtovirus, Erarovirus and Turncurtovirus, based on their insect vector, host range and genomic characteristics (Varsani et al., 2014). Among these viruses, whitefly [Bemisia tabaci (Gennadius)]transmitted begomoviruses are considered to be one of the largest and most important group of plant viruses infecting a wide range of crops, particularly in tropical and subtropical regions of world. The leaf curl disease caused by begomovirus belongs to family Geminiviridae which affects both mesta and cotton belong to the malvaceae family. It is of great concern because cotton and mesta crop has covered larger area in North Karnataka. Since, there is no much research work was done on this, the work has been carried out for investigations on modes of transmission, virus -vector relationship of the virus in relation to disease spread.

\section{Materials and Methods}

\section{Maintenance of virus pure culture under insect proof condition}

Diseased mesta plants exhibiting typical symptoms of leaf curl were collected from different formers field and the pure culture of the virus was maintained under glasshouse (Fig. 1) and used for further transmission studies.

Source and maintenance of whitefly ( $B$. tabaci) culture

Initially, Tobacco whiteflies (B. tabaci) were collected from brinjal plants at Entomology plot, New area and Agricultural Engineering research field, UAS Raichur, Karnataka, India and the colony was established on freshly grown cotton (Gossypium hirsutum cv. DCH2) and brinjal (Solanum melongeana L.) plants kept in insect proof net house (Fig. 2). There after one generation, freshly emerged whiteflies were collected using an aspirator and were transferred onto freshly grown cotton plants kept in an insect proof net house. The colony developed, from the egg was referred to be pure (a-viruliferous) and further the colony of whiteflies were used for further studies.

\section{Raising of healthy mesta seedlings}

The seeds obtained from healthy mesta plants were sown and maintained in insect proof cages. Seedlings at two leaf stage were inoculated with 20 whiteflies for $24 \mathrm{~h}$ of inoculation access feeding period after $24 \mathrm{~h}$ acquisition access feeding on leaf curl infected mesta plants. The inoculated seedlings were kept in insect proof glasshouse for symptom development. Observations were made on time for initial and final symptoms expression and type of symptoms. Further the healthy mesta seedlings were also used for symptom characterization by transmitting leaf curl virus of mesta through different means of transmission.

\section{Whitefly transmission}

The healthy whiteflies maintained on cotton and brinjal plants were collected using an 
aspirator and allowed to feed on leaf curl infected mesta plant for a different acquisition access period viz., $10 \mathrm{~min}, 30 \mathrm{~min}, 1 \mathrm{~h}, 2 \mathrm{~h}, 3$ h, $6 \mathrm{~h}, 12 \mathrm{~h}, 24 \mathrm{~h}$. The viruliferous whiteflies were again transferred to healthy mesta seedlings to inoculate the virus for a period of $24 \mathrm{~h}$. Later the whiteflies were killed using systemic insecticide triazophos at $1 \mathrm{ml} / \mathrm{l}$. The inoculated seedlings were maintained in insect proof cages till the expression of symptoms.

\section{Dodder transmission}

The dodder seeds collected from the vein twined and established on mesta plants. The seeds collected have been sown in pot containing leaf curl infected mesta plants, the seeds have germinated and started twining to the infected plants after 12-15 days after sowing. After complete establishment of the dodder, the veins are twined to the series of healthy seedlings of mesta and kept in a insect proof cages for further symptom expression. The symptoms expressed were recorded.

\section{Graft transmission}

Healthy seedlings of mesta were grown in pots and maintained in insect proof cages. The healthy scions are collected and grafted on to the root stock of leaf curl virus infected mesta plants through wedge grafting. The scion and root stocks were tied tightly with thin plastic strips. Plants were maintained under insect proof cages and monitored for the development of disease symptoms over a period of time and recorded the symptoms.

\section{Sap transmission}

Mesta leaf samples showing typical symptoms of leaf curl along with the healthy samples were taken separately for mechanical sap transmission. The samples were washed in tap water to remove the dust particles adhering to them and dried between the folds of blotting paper. The leaves were then macerated in chilled mortar and pestle using potassium phosphate buffer $(\mathrm{pH} 7.0,0.05 \mathrm{M})$ at the rate of $1 \mathrm{ml} / \mathrm{g}$ of leaf tissue. The leaf extract was filtered through Whatman no. 47 filter paper, then add ceilite (600 mesh) at the rate of 0.025 $\mathrm{g} / \mathrm{ml}$ to the extract and $0.02 \%$ of mercapta ethanol. The inoculum was applied gently on the upper surface of the leaves and rubbed unidirectionally, with a small piece of absorbent cotton wool. After 10-15 minutes, the inoculated leaves were washed with a fine jet of distilled water from a squeeze bottle to remove the excess of inoculum. The inoculated plants were maintained under insect proof cages for symptoms expression over a period of time.

\section{Number of whiteflies (B. tabaci) required for transmission of disease}

To determine the minimum number of whitefly required for successful transmission of virus onto a healthy mesta seedlings (Economic threshold level ETL), whiteflies were tested at different number varied from 1, 2, 4, 5, 10, 15 and 20/plant. Method of virus acquisition and inoculation was followed for each test number, 20 plants were inoculated. After $24 \mathrm{~h}$ of each acquisition access period and inoculation access period, seedlings were sprayed with triazophos at $1 \mathrm{ml} / \mathrm{l}$ and kept for symptoms expression in insect proof cages. Observations were made on number of seedlings exhibits leaf curl symptoms among the total number of plants inoculated per each test number of $B$. tabaci.

\section{Viral acquisition and inoculation assay}

The healthy whiteflies maintained on cotton and brinjal plants were collected using an aspirator (Fig. 3) and allowed to feed on leaf curl virus infected mesta leaf for different acquisition access periods viz., $10 \mathrm{~min}, 30$ min, $1 \mathrm{hr}, 2 \mathrm{hr}, 3 \mathrm{hr}, 6 \mathrm{hr}, 12 \mathrm{hr}$ and $24 \mathrm{hr}$ 
(AAP). The viruliferous vectors of the respective AAP were again transferred to healthy mesta seedlings to inoculate the virus for a specific period of $24 \mathrm{hr}$. In order to standardise the inoculation access period required for the disease transmission healthy colonies of whiteflies were allowed to feed on leaf curl virus infected mesta leaf sample for a specific period of $24 \mathrm{hrs}$. After $24 \mathrm{hrs}$ of AAP, such viruliferous whiteflies were allowed to feed on healthy mesta seedlings for different inoculation access periods viz., $10 \mathrm{~min}, 30$ min, $1 \mathrm{hr}, 2 \mathrm{hr}, 3 \mathrm{hr}, 6 \mathrm{hr}, 12 \mathrm{hr}$ and $24 \mathrm{hr}$ (IAP) to inoculate the virus (Fig. 4).

After, respective periods of inoculation and acquisision access periods, whiteflies were killed using systemic insecticide triazophos at $1 \mathrm{ml} / \mathrm{l}$. Later inoculated seedlings were maintained in insect proof cages till the expression of symptoms. Observations were recorded on AAP and IAP required to achieve minimum and maximum per cent transmission based on number of seedlings exhibits diseases symptoms upon inoculation of virus.

\section{Results and Discussion}

The biological characterization of mesta leaf curl disease was studied to know the different symptoms exhibited over a period of time, through different modes of transmission viz., whiteflies, dodder, grafting and sap. The results obtained are presented here.

\section{Whitefly transmission}

Whiteflies are considered as an efficient vectors in transmission of begomovirus (leaf curl). A single viruliferous whitefly can transmit the disease to an extent of 40 per cent. Among 75 plants inoculated, 68 showed symptoms, with a mean incidence of 90.66 per cent (Table 1). Twenty viruliferous whiteflies were used per seedling with given a $24 \mathrm{~h}$ of AAP and IAP to achieve maximum transmission efficiency (100\%). The affected plants showed the characteristics symptoms such as, vein clearing, vein thickening, chlorosis, upward curling, leathery leaves, twisting of petioles, reduction in leaf size and stunted growth of the plant (Fig. 5) The initial symptoms were observed at 18 days after inoculation and the final symptoms were observed at 45-48 days after inoculation.

The results are in conformity with other whitefly transmitted geminiviruses in different crops such as hibiscus, (Rajeshwari et al., 2005) and sunflower (Vindyashree et al., 2016). In contrary Paul et al., (2009) reported that, minimum of five and 30 whiteflies were required per plant for transmission of kenaf leaf curl disease to an extent of 10 and 70 per cent respectively.

\section{Dodder (Cuccuta subinclusa) transmission}

The transmission of leaf curl disease of mesta through dodder was achieved from mesta to mesta. The healthy mesta plants connected by strands of dodder established on infected plants. The transmission efficiency was ranged from 60 to 100 per cent with a mean incidence of 73.33 per cent (Table 1 ).

The parasitized plants showing the initial symptoms like, vein clearing and vein thickening at 27 days of after parasitisation. Further symptoms like upward curling of leaves, leathery leaves and twisting of petioles, small sized leaves and stunted growth of plant (Fig. 6) can be recorded at 45-48 days after inoculation.

Same kind of work has been carried out by Welliver (1992) in tomato for the tomato ring spot virus disease (TmRSV) through dodder (Cuscuta gronovii) in Chenopodium quinoa and Garnier and Bove (1983) in periwinkle from sweet orange plant infected with yellowing disease 


\section{Graft transmission}

Wedge grafting method was employed for the transmission of leaf curl disease of mesta from infected mesta to healthy mesta. The grafting was carried out by using healthy scion to infected root stock. The successful grafting was recorded in 30 plants among 50 plants grafted. The transmission of the virus was ranged from $40-80$ per cent with a mean incidence of 60 per cent (Table 1). The symptoms were observed at 33-48 days after grafting. The grafted plants exhibited the symptoms such as vein clearing, vein thickening, upward curling of leaves, leathery leaves, small sized leaves and stunted growth of the plants (Fig. 7).

Similar kind of results were obtained in Jatropa Jatropa mosaic virus (JMV) through grafting, (Aswathanarayana et al., 2007). Beyene et al., (2013) reported the transmission of cassava brown streak virus pathogen by chip grafting.

\section{Sap transmission}

The sap was obtained from the leaf curl infected mesta plants using sodium and pottssium phosphate buffer. The sap was inoculated to 30 days old mesta and Nicotiana benthamiana seedlings. Among the 45 mesta plants inoculated, 25 plants expressed the leaf curl symptoms after 30 days of inoculation with a mean incidence of 28.88 per cent. Similarly out of $30 \mathrm{~N}$. benthamiana plants inoculated 12 plants showed the symptoms with mean incidence of 39.95 per cent with a average incidence of 34.41 per cent (Table 1). The sap inoculated plants showed only the vein clearing, vein thickening and leaf curling symptoms in both mesta and $N$. benthamiana plants (Fig. 8).

These results are in accordance with some of the works carried out in different crops. Jha and Rayachaudhuri (1956) demonstrated that, CMV was sap transmitted and produced systemic symptoms on $N$. tabacum, $N$. glutinosa, Solanum nigrum, Cucumis melo, safflower, D. stramonium and potato.

Cucumber Mosaic Virus (CMV) was mechanically sap transmissible (Iqbal et al., 2011) and Sohrab et al., (2014) reported the sap transmission of tomato leaf curl New Delhi virus to sponge guard. The virus can be transmitted by sap inoculation to sponge gourd, ridge gourd (Lufa acutangula), and Nicotiana benthamiana using standardized buffer. The sap transmission was confirmed by using the total DNA isolated from symptomatic leaves and PCR amplification of $\mathrm{CP}$ genes using specific primers

\section{Virus vector relationship}

Number whiteflies required, AAP, IAP required in relation to spread of leaf curl disease of mesta are presented here. To ascertain the minimum number of $B$. tabaci required for efficient transmission of mesta leaf curl disease, different number of whiteflies viz., 1, 2, 4, 5, 10, 15, and 20 per plant were used for inoculation. Viruliferous whiteflies were enclosed on test plants with 24 $h$ of acquisition access period (AAP) and inoculation access period (IAP). The results showed that, single whitefly was able to transmit mesta leaf curl disease with 40 per cent efficiency.

The transmission efficiency increased to more than 60 per cent when four viruliferous whiteflies were caged on healthy mesta seedlings. Transmission efficiency of 100 per cent was achieved with 20 viruliferous whiteflies used per plant. This indicates that the single whitefly is enough to transmit the disease. Further number of insects and the transmission efficiency was positively correlated. 
Table.1 Different modes of tranmsission of leaf curl disease of mesta

\begin{tabular}{|c|l|c|}
\hline SI. No. & Modes of transmission & Transmission (\%) \\
\hline 1. & Whiteflies & 90.66 \\
\hline 2. & Dodder & 73.33 \\
\hline 3. & Grafting & 60.00 \\
\hline 5. & Sap & 34.41 \\
\hline
\end{tabular}

Table.2 Virus-vector relationship in relation to disease spread

\begin{tabular}{|c|c|c|c|c|c|}
\hline $\begin{array}{c}\text { No. of } \\
\text { whiteflies }\end{array}$ & $\begin{array}{c}\text { Transmission } \\
\%\end{array}$ & AAP & $\begin{array}{c}\text { Transmission } \\
\%\end{array}$ & IAP & $\begin{array}{c}\text { Transmission } \\
\%\end{array}$ \\
\hline 1 & 40 & $10 \mathrm{~min}$ & 45 & $10 \mathrm{~min}$ & 30 \\
\hline 2 & 55 & $30 \mathrm{~min}$ & 60 & $30 \mathrm{~min}$ & 60 \\
\hline 4 & 65 & $1 \mathrm{~h}$ & 60 & $1 \mathrm{~h}$ & 60 \\
\hline 5 & 90 & $2 \mathrm{~h}$ & 65 & $2 \mathrm{~h}$ & 70 \\
\hline 10 & 95 & $3 \mathrm{~h}$ & 80 & $3 \mathrm{~h}$ & 80 \\
\hline 15 & 95 & $6 \mathrm{~h}$ & 85 & $6 \mathrm{~h}$ & 85 \\
\hline 20 & 100 & $12 \mathrm{~h}$ & 100 & $12 \mathrm{~h}$ & 95 \\
\hline- & - & $24 \mathrm{~h}$ & 100 & $24 \mathrm{~h}$ & 100 \\
\hline
\end{tabular}

Fig.1 Maintenance of mesta leaf curl disease samples in insect proof cages

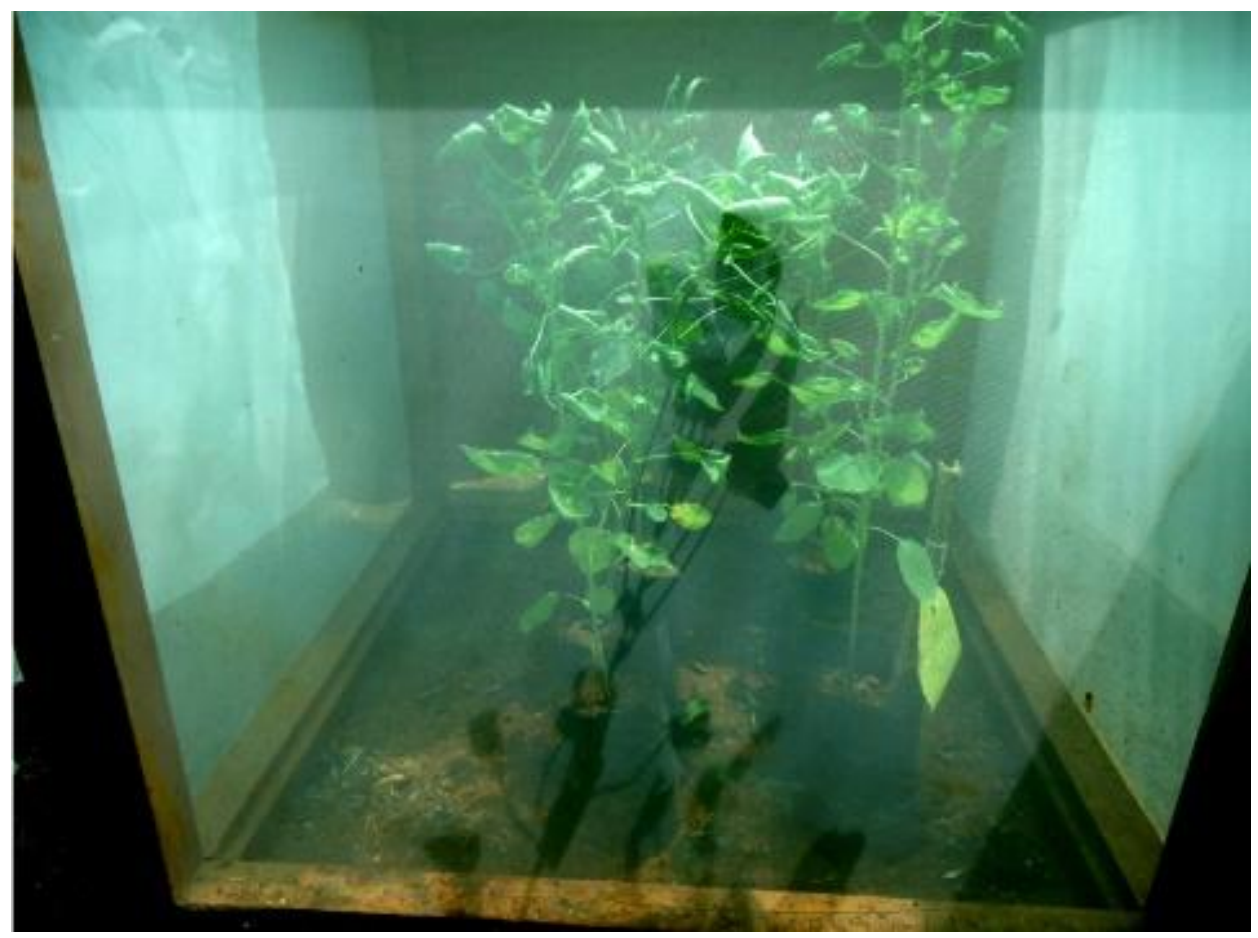


Fig.2 Maintenance of whitefly culture on cotton and brinjal plants
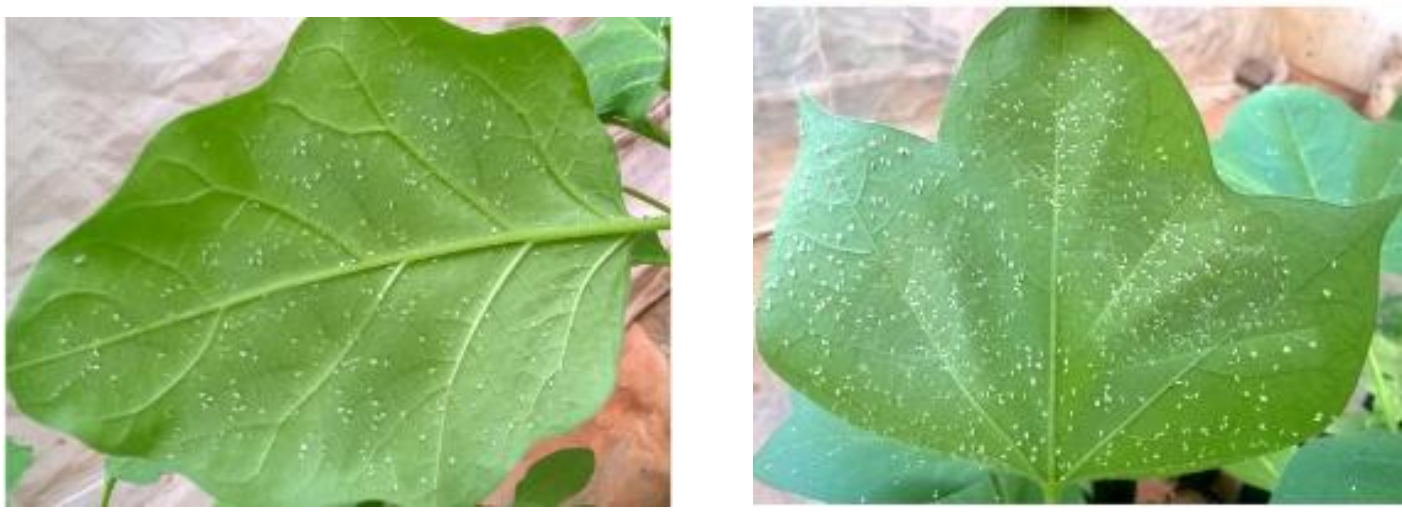

Fig.3 Materials used in transmission studies
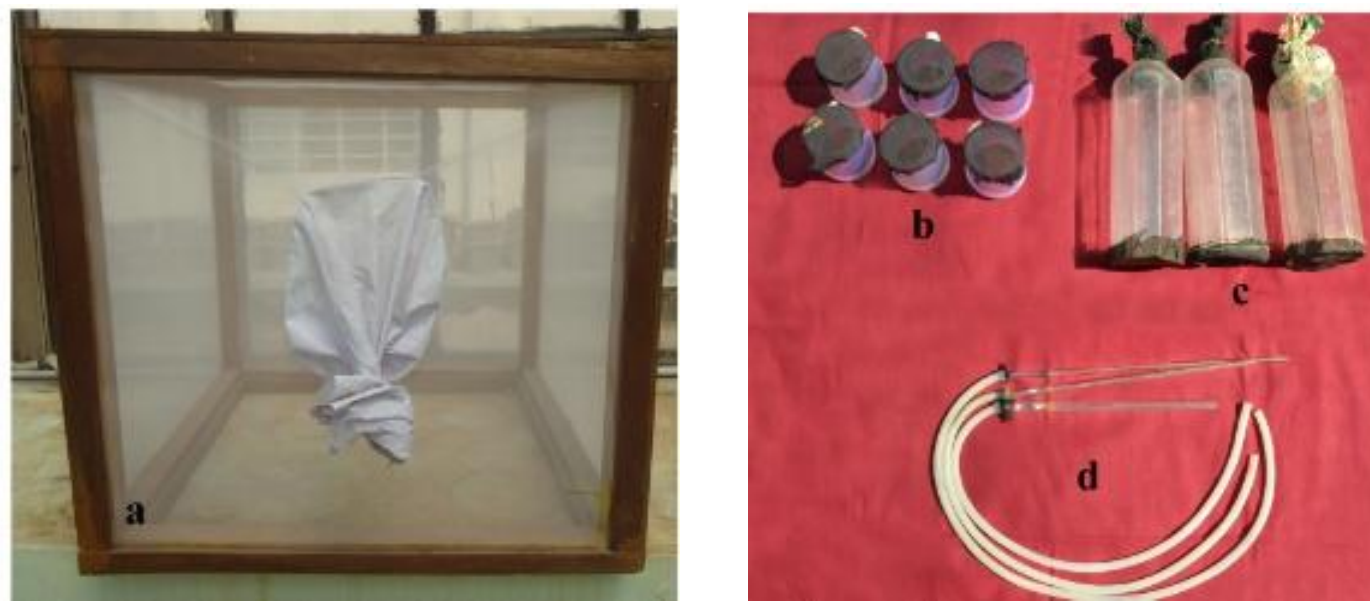

a) Insect proof cage b) Inoculation tubes c) Acquisition tubes d) Aspirators

Fig.4 Acquisition and inoculation of leaf curl virus from whiteflies

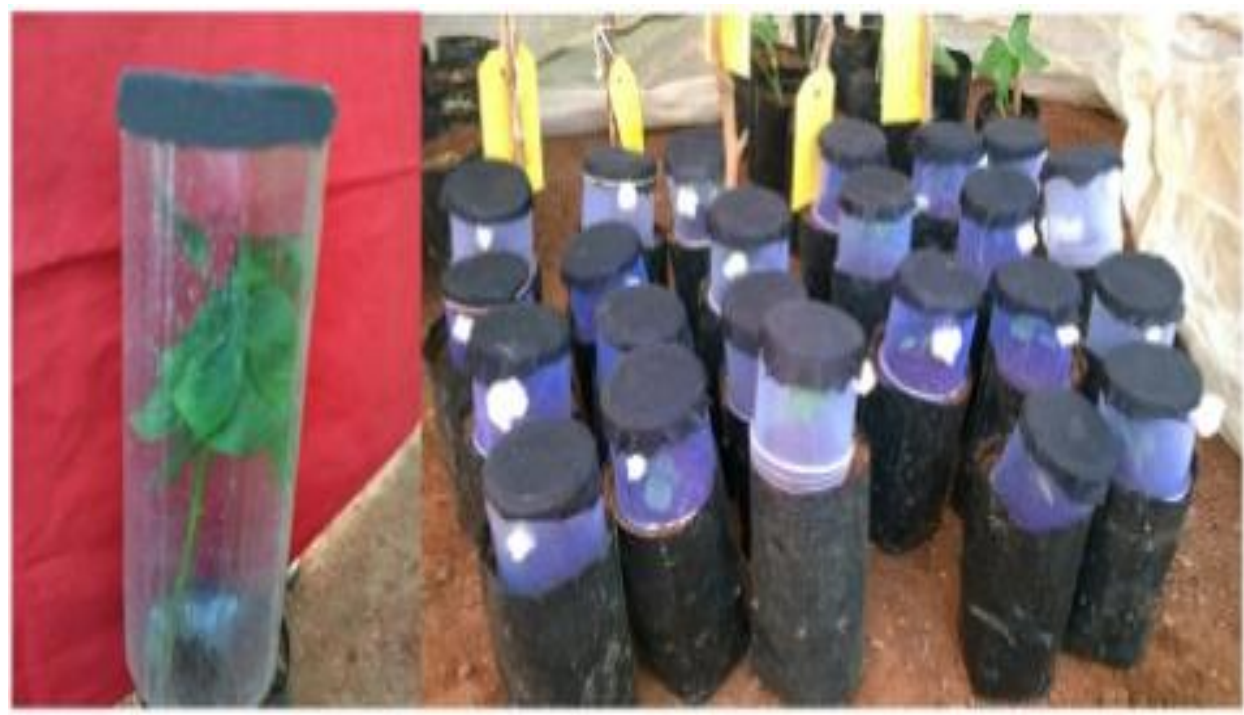


Fig.5 Whitefly transmission Fig.6 Dodder transmission Fig.7 Graft transmission

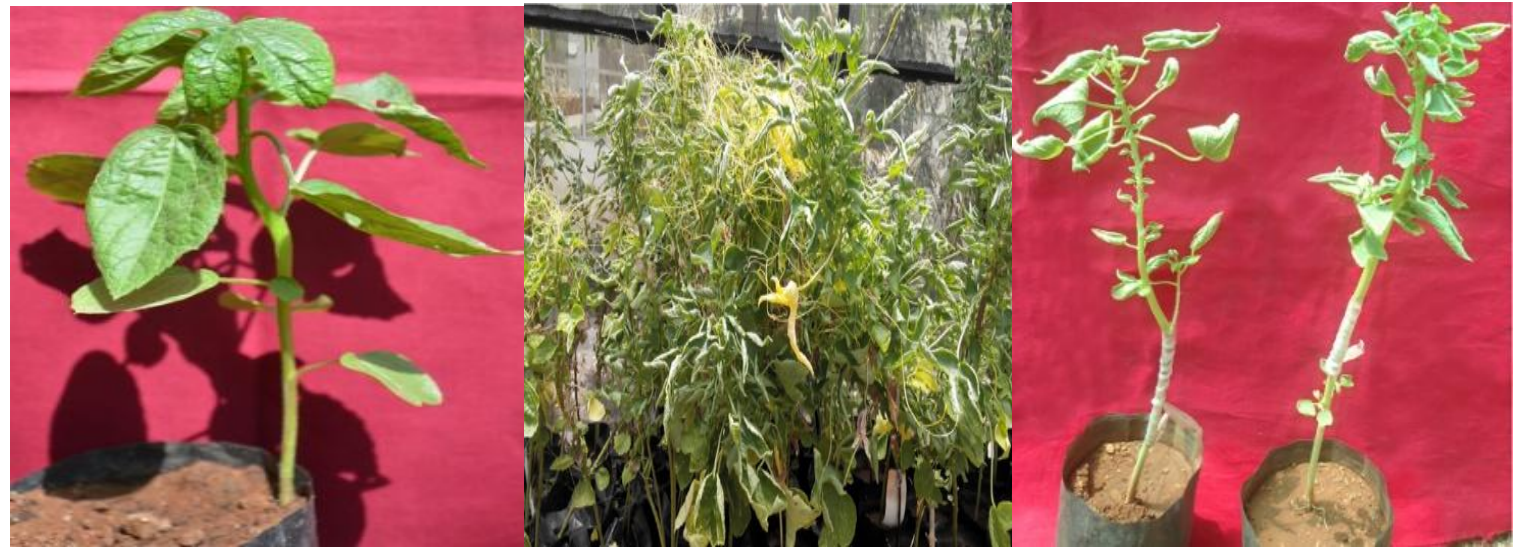

Fig.8 Sap transmission
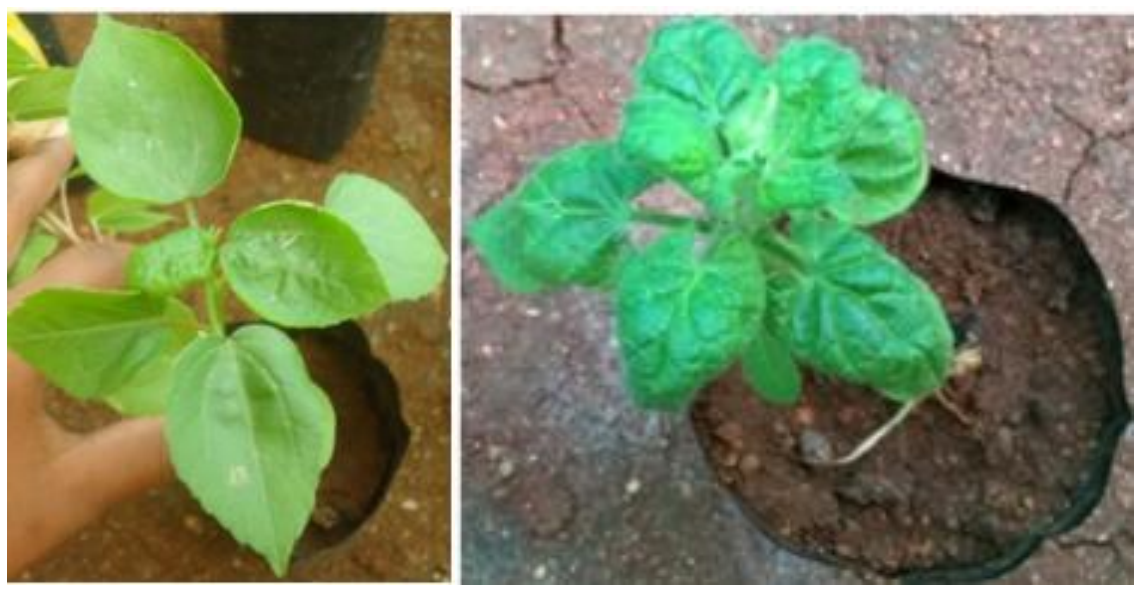

Similar findings were reported by Mathew (1988) in cassava mosaic virus. 100 per cent transmission of cassava mosaic virus was obtained with 40 or more whiteflies per seedling. Mandal and Muniyappa (1991) and Nateshan (1992) were observed that 15 viruliferous $B$. tabaci per plant were required for 100 per cent transmission of Croton yellow vein mosaic virus (CYVMV) and Cotton leaf curl virus (CLCuV) respectively.

\section{Viral Acquisition and inoculation Assay for transmission of leaf curl disease of mesta}

After standardizing the number of whiteflies required for the maximum disease transmission, a group of 20 non-viruliferous adult whiteflies was allowed to feed on leaf curl infected mesta plant for different AAP from $10 \mathrm{~min}$ to $24 \mathrm{~h}$. The 20 viruliferous whiteflies were then inoculated to healthy plants enclosed for $24 \mathrm{~h}$ IAP in micro cages to estimate the comparative efficiency of AAP of B. tabaci. The studies indicated that a minimum 10 min of AAP was necessary for B. tabaci to acquire virus, which resulted in 45 per cent transmission. More than 50 per cent tansmission was observed with 30 min of AAP. An AAP of at least $12 \mathrm{hr}$ was required for 100 per cent transmission of the disease from whiteflies. It has been shown that the per cent transmission of the disease increased with the increase in AAP. A group of 20 nonviruliferous adult whiteflies were allowed to 
access leaf curl disease of mesta on infected seedlings for $24 \mathrm{~h}$ of AAP. The inoculation access period varied from $10 \mathrm{~min}$ to $24 \mathrm{~h}$. Minimum IAP required by viruliferous whiteflies to transmit leaf curl virus of mesta was $10 \mathrm{~min}$ to achieve 30 per cent transmission efficiency. An IAP of $24 \mathrm{~h}$ was required to achieve 100 per cent transmission with $24 \mathrm{~h}$ AAP. The results indicated that per cent transmission increased with the increase of IAP (Table 2).

Similar findings were reported by Muniyappa et al., (1991) in Horsegram yellow vein mosaic virus transmission. whiteflies required a minimum of 30 min AAP to transmit Horse gram yellow vein mosaic virus in Horsegram under greenhouse studies and Rajeshwari et al., (2005) reported that a minimum of $25 \mathrm{~B}$. tabaci adults were required for the transmission of CLCuMV-Hib[Ban] with 20 per cent efficiency. The transmission rate increased to 70 per cent when 50 adults per test plant were used. $B$. tabaci adults required a minimum feeding period of $12 \mathrm{~h}$ on diseased hibiscus plants for acquisition of CLCuMV-Hib[Ban] and achieved 30 per cent transmission rates. The transmission efficiency increased to only 60 per cent with 48-h AAP. B. tabaci adults required a minimum IAP of $24 \mathrm{~h}$ and achieved 30 per cent transmission rates, whereas transmission was 50 per cent following an IAP of $48 \mathrm{~h}$.

Paul et al., (2009) studied the transmission of kenaf leaf curl disease using different acquisition access period and inoculation access period, a minimum of $6 \mathrm{~h}$ of AAP and IAP is required for disease incidence (10 per cent) whereas maximum disease incidence of 70 per cent has been observed in $24 \mathrm{~h}$ of AAP and IAP.

The leaf curl disease of mesta can be successfully transmitted though different means of transmission viz., whitefly, dodder, grafting and sap from mesta to mesta and exhibited the characteristics symptoms similar to the symptoms of natural field conditions.

Single viruliferous whitefly can transmit the mesta leaf curl disease. However 20 viruliferous whiteflies were required for 100 per cent transmission. A minimum period of 10 min was necessary for $B$. tabaci to acquire and to inoculate the mesta leaf curl virus and maximum transmission of the disease was recorded at $24 \mathrm{~h}$ of AAP and IAP (100\%).

\section{Acknowledgement}

All the authors acknowledge their heartfelt gratitude to UAS, Raichur for the financial support extended for conducting the present investigation.

\section{References}

Aswathanarayana, D. S., Rangaswamy, K. T., Shankarappa, K. S., Maruthi, M. N., Lakshminarayana Reddy, C. N., Rekha, A. R. and Keshava Murthy. K. V., 2007. Distinct begomoviruses closely related to cassava mosaic viruses cause Jatropha mosaic disease in India. Inter. J. Virol., 3 (1): 1-11.

Beyene, G., Wagaba, H., Trembley, C., Alicai, T., Fauquet, C. M. and Taylor, N. J., 2013. Efficient transmission of cassava brown streak disease viral pathogen by chip bud grafting. $B M C$ Research Notes, 6: 516.

Iqbal, S., Ashfaq, H. and Shah, H., 2011. Biological characterization of Pakistani isolates of Cucumber mosaic cucumovirus (cmv). Pak. J. Bot., 43: 3041-3047.

Jha, A. and Rayachaudhuri, S. P., 1956. Mosaic disease of chilli (C. frutescens L.). J. Agric. Sci., 26: 217 -222.

Mandal, B. and Muniyappa, V., 1991. Isolation and detection of croton yellow 
vein mosaic virus, a whitefly transmitted geminivirus. Fitopatol. Brasileria, 16: 177-180.

Mathew, A. V., 1988. Studies on Indian cassava mosaic virus disease. Ph.D. Thesis, Univ. Agric. Sci., Bangalore (India), pp. 237.

Muniyappa, V., Swanson, M. M., Duucan, G. H. and Harrison, B. D., 1991. Particle purification, properties and epitope variability of Indian tomato leaf curl geminivirus. Ann. Appl. Bio., 118: 595604.

Nateshan, H. M., 1992. Biological properties of cotton leaf curl geminivirus. Ph.D. Thesis, Univ. Agri. Sci., Bangalore.

Paul, S., Ghosh, R., Roy, A., Mir, J. I. and Ghosh, S. K, 2006. Occurrence of a DNA $\beta$ containing begomovirus associated with leaf curl disease of kenaf (Hibiscus cannabinus L.) in India. Ausralian Plant Dis. Notes, 1: 29-30.

Paul, S., Ghosh, R., Roy, A., Mir, J. I. and Ghosh, S. K, 2009. Biological and molecular variability of the begomoviruses associated with leaf curl disease of kenaf in India. J. Plant Pathol., 91 (3): 637-647.

Rajeshwari, R., Reddy, R. V. C., Maruthi, M. N., Colvin, J., Seal, S. E. and Muniyappa, V., 2005. Host range, vector relationships and sequence comparison of a begomovirus infecting hibiscus in India. Ann. Appl. Biol., 147: 15-25.

Sohrab, S. S., Karim, S., Varma, A., Azhar, E. I., Abuzenadah, A, M. and Manda, B., 2014. Sap transmission of tomato leaf curl New Delhi virus infecting sponge gourd in Northern India. J. Plant Interactions, 9: 241-248.

Varma, A. and Malathi, V. G., 2003. Emerging geminivirus problems: A serious threat to crop production. Ann. Appl. Biol. 142: 145-164.

Varsani, A., Muhire, B. M. and Martin, D. P., 2014. A virus classification tool based on pairwise sequence alignment and identity calculation. J. Pone, 0108277p. 26: 9(9).

Vindhyashree, M, Maheshwai, S. and Govindappa, M. R., 2016. Biological and molecular detection of leaf curl begomovirus disease of sunflower (Helianthus annus L.) in tobacco (Nicotiana benthamiana). Int. J. Scientific Res., Publications, 6: ISSN 2250-3153.

Welliver, R. A., 1992. Dodder transmission of tomato ring spot virus. J. Plant Dis., 76: p. 642.

\section{How to cite this article:}

Humma Ambuja, D.S. Aswathanarayana, M.R. Govindappa, M.K. Naik and Patil, M.G. 2018. Different Modes of Transmissibility and Virus-Vector Relationship in the Occurrence of Leaf Curl Disease of Mesta (Hibiscus subdariffa L.). Int.J.Curr.Microbiol.App.Sci. 7(01): 627-636. doi: https://doi.org/10.20546/ijcmas.2018.701.076 